\title{
THE QUALITY OF ASSESSMENT INSTRUMENT ON THE IMPLEMENTATION OF INTEGRATED CURRICULUM AT UIN SUSKA RIAU
}

\author{
Mas`ud Zein \\ Universitas Islam Negeri Sultan Syarif Kasim Riau, Pekanbaru, Indonesia \\ masud.zein@uin-suska.ac.id
}

\begin{abstract}
This study aims to determine the quality of assessment in the implementation of UIN Suska Riau curriculum integration and the difference in assessment quality in the implementation of curriculum integration in terms of lecturers' educational background. This was descriptive quantitative research to explore the data from various informants and resources in accordance with the issues reviewed. Furthermore, the informants in this study were lecturers of UIN Suska Riau. The data were collected using interviews and documentation to find out the results of the study using a test description and to determine the differences of assessment quality in the curriculum integration implementation in terms of lecturers' educational background seen from the mean (average) of each group. Based on the results of research and analysis, the assessment instrument quality classified as "good" with a percentage of $70.57 \%$ and there is a difference between the assessment instrument quality of education and non education lecturers in the curriculum integration implementation of UIN Sultan Syarif Kasim Riau.
\end{abstract}

Keywords: assessment instrument, implementation, integrated curriculum

\begin{abstract}
Abstrak
Penelitian ini bertujuan untuk mengetahui kualitas asesmen dalam pelaksanaan integrasi kurikulum UIN Suska Riau dan perbedaan
\end{abstract}


kualitas asesmen dalam pelaksanaan integrasi kurikulum dalam hal latar belakang pendidikan dosen. Penelitian ini menggunakan penelitian kuantitatif deskriptif untuk menggali data dari berbagai informan dan sumber daya sesuai dengan isu yang ditinjau. Informan dalam penelitian ini terdiri dari dosen UIN Suska Riau. Pengambilan data menggunakan wawancara dan dokumentasi untuk mengetahui hasil penelitian dengan menggunakan deskripsi uji dan untuk mengetahui perbedaan kualitas instrumen penilaian dalam pelaksanaan integrasi kurikulum dalam hal latar belakang pendidikan dosen dilihat dari mean (rata) dari masingmasing kelompok. Berdasarkan hasil penelitian dan analisis, instrumen penilaian kualitas tergolong "BAIK" dengan persentase 70,57\% serta ada perbedaan antara kualitas instrumen penilaian dosen pendidikan dan non pendidikan dalam pelaksanaan integrasi kurikulum UIN Sultan Syarif Kasim Riau.

Kata Kunci: Instrumen penilaian, Implementasi, Kurikulum Terpadu

\section{A. Introduction}

UIN SUSKA (Sultan Syarif Kasim) Riau is a State University under the supervision of the Ministry of Religious Affairs. It has also sought to improve the quality of education through the application of curriculum integration. As the vision of UIN Sultan Syarif Kasim Riau, "to promote the State Islamic University as a major institution of higher education that develops and integrate the teachings of Islam, science, technology and art in Southeast Asia 2013." UIN Suska Riau is an Islamic educational institutions have a concept in integrating social sciences, if necessary, also include the integration of sciences. Some reasons for the commencement of the integration of science, among other things: 1) that at UIN is already promote the integration of science, 2) that the UIN classified as multi-concept or multi lecturer who has long taught both disciplines (general science and theology), so it can be expected the emergence of a new formulation, a new formulation that is pithy and diamonds for the advance of integration and Islamization of science (Yusuf, 2011: 11)

Although curriculum integration has been applied, the assessment instruments used to assess the students are still using a scoring system that is used on the former curriculum. Assessment instruments in the curriculum contains only some components; individual score, structured, mid semester, and final semesters. 
Assessment as it assumed only include cognitive or intellectual, otherwise, affective and psychomotor aspects are neglected. It certainly can not measure the achievement of lecture-based curriculum integration at the university SUSKA.

Various attempts were made, which were not fully resolve the issue. Some of the things that cause unsuccessful implementation of the concept of curriculum integration, among others: the curriculum is still designed separately without a curriculum guide and integrated learning and assessment forms that are not yet using the right instruments to support the establishment of the knowledge integration, in addition to the ability of faculty and facilities are inadequate.

Meanwhile, the integrated curriculum is a way to teach students who seek negate the boundary between subjects and make learning more meaningful for students. This idea is to teach what is around them, or focus on concentration that students can identify what is in the environment. Other terms of curriculum integration is an integrated curriculum. Integration in the curriculum, the courses focused on a particular issue or topic, for example, a problem in which all courses are designed with reference to a particular topic. What is presented on campus, adjusted to life off-campus students. Courses on campus to help students in dealing with various problems outside campus. However, this kind of shape curriculum implemented through the lessons units, where a unit has a goal implies for students who poured in the form of a problem. For solving the problem, students are directed to perform activities that are interrelated with each other. Through the integration is expected to be shaped, also the integrity of personality of students in accordance with their communities. Therefore, what is taught on campus should be completely adapted to the situation, problems and needs of life in society.

The model development efforts, is done by re-designing and developing a common curriculum subjects (science) that have been or are applied in the campus into a model of curriculum development to integrate science with theology. The model is meant here is a model that can be used as a reference (model) to develop a curriculum for a public lecture at the college into a model that can integrate course material science with theology. 
Accordingly, it is necessary to find a model of judging instrument that can be used as an evaluation tool that is ideal in the implementation of integration based curriculum at the university SUSKA. With that focus, all of the above problems as well as to look for solutions to the curriculum designed separately, there is no model/curriculum guide and integrated learning and assessment forms were not using appropriate instruments.

The instrument plays an important role in determining the quality of a research and assessment. The function of the instrument is revealed facts into data (Djaali and Pudji Muljono, 2004: 6). According Arikunto, the data is a depiction of the variables studied and serve as a proof of the hypothesis, whether or not the data is dependent on whether or not the data collection instruments (Arikunto, 2010: 35). To collect research data, the lecturers can use the instruments which have been provided or so-called standardized instruments and also with self-made instruments. If the standardized instrument provided the teacher can immediately use of such instruments, but if those instruments are not available or not standardized then the lecturers must be able to develop a self-made instrument to be standardized so that it becomes viable instrument according to its function. In accordance with the formula given, the study aims to find out: 1) the quality of assessment instruments in the implementation of curriculum integration UIN Suska Riau; and 2) the significant difference in the quality of assessment instruments in the implementation of curriculum integration in terms of educational background of the lecturers.

In this research uses descriptive quantitative research methods on the grounds that in this study seeks to explore the data, the data is a comparison of quality achievement instrument with defined criteria. Then proceed by comparing the quality scores of instruments that comes from the background of lecturers who teach religion and non-religion. Furthermore, the respondent provide interpretation, therefore it can rise to a finding or developing findings and provide information as well as an overview of the implementation. This study will be conducted in SUSKA UIN Riau which has drawn up a Curriculum Integration Model. The research data is collected by using as the following techniques: interview and 
documentation. Data analysis techniques, which is used in this study are: 1) to determine the quality of assessment instrument in the implementation of curriculum integration UIN Suska Riau, which uses test description; and 2) to determine a significant difference in the quality of assessment instruments in the implementation of curriculum integration in terms of educational background of lecturers, that can be found from the mean (average) of each group.

\section{B. Result and Discussion}

\section{Data presentation}

\section{a. The Quality of Assessment Instrument on the Implementation of Curriculum Integration of UIN SUSKA Riau}

The quality of assessment instruments in the implementation of curriculum integration UIN Suska Riau obtained through the descriptive test of the items. Based on the results of research and analysis, the researchers found that the quality assessment instrument classified as "GOOD" with a percentage of $70.57 \%$. It is seen from the quality of each item in which every item on average have GOOD quality. For more details can be seen on the attachment. Instruments are measuring instruments, which is used to obtain qualitative and quantitative information about the variation in the characteristics of the study variables objectively (Hajar, 1996: 160). Meanwhile, according to Djaali and Muljono, the instrument is a tool that meets the academic requirements, which can be used as a tool to measure an object measuring or collecting data about a variable (Djaali and Pudji Muljono, 2004: 6).

The Assessment have different interpretations of various educational experts, but most experts are commonly said in English by the term of assessment evaluation. According to Sudijono (1995: 4) that the assessment means assessing something. While "to assess" implies taking a decision against something by basing on the size of the good or bad, healthy or sick, clever or stupid, and so on.

Based on the above explanation can be argued that the assessment tool is a tool that meets the academic requirements, so it can be used as a tool to measure an object, or collecting data about a variable. In the field of education, instrument is used to measure 
student achievement, factors suspected to have a relationship or influence on learning outcomes, development of student results, the success of the learning process of teachers, and the successful achievement of a particular program. There are two types of techniques are often used in assessment (evaluation), which are test and non-test.

First, a test, according to Mukhtar Bukhari in his book Techniques of Evaluation that the test was a trial held to determine whether or not the results of certain subjects in a student or group of students (Arikunto, 2010: 32). In terms of the usefulness of measuring student learning outcomes, then differentiated into the three kinds of tests, namely: diagnostic tests, tests of formative and summative. Second, non-test, includes in the group of non-test techniques are as follows (Arikunto, 2010: 27-31): a graduated scale, a questionnaire, a list of matches, interview, observation and biography. In developing the instrument, Tuckman has indicated the steps that can be followed to the goals setting and variables to be measured, determining the indicator, determining grain instrument, as well as testing and evaluating instrument (Lubis and Zubaedi, 2008: 42)

According to Stephen Isaac and William B. Michael (1982: $151)$, to assess the cognitive and affective aspects, there are several models of assessment instrument that can be used are: standardized achievement and ability test, standardized self inventories designed and standardized rating scale and check list. Some models of evaluation proposed by Arifin as follows (Arifin, 2010: 74-83):

First, Model Tyler. This model is built on two premises. The first, aimed at the evaluation of the behavior of learners. Secondly, the evaluation must be conducted on the behavior of early learners before implementing the learning activities and after implementing the learning activities (result). According to Tyler, knowledge of measurement and evaluation of knowledge apart and is a process in which the measurement is only one of several possibilities to support the achievement of evaluation (Sukardi, 2008: 56-57). Second, Model Driven. This evaluation model is commonly used learning goals and specific learning objectives as criteria to determine of success. This model was considered more practical for determining the desired result with the formulation that can be measured. The purpose of 
this model is to help teachers to set goals and explain the relationship between the destination with activities. Third, Measurement Model. This model is very focused on measurement activities. Measurements used to determine the quantity of a trait (attributes) that are owned by a particular object, person or event, in the form of units of a certain size. The object of evaluation in this model is the behavior of learners, including the results of learning (cognitive), disposition, attitudes, interests, talents, and also aspects of personality of students.

Fourth, the Compliance Model. On this model, evaluation is an activity to look at the suitability (congruence) between destination with the learning outcomes have been achieved. The object of evaluation is the behavior of learners, the desired change in behavior at the end of educational activities, both concerning cognitive, affective and psychomotor aspects. Fifth, Educational System Evaluation Model. According to this model, evaluation is a process for convincing decision, gather information, choose the appropriate information and analyze the information, therefore it can be prepared a report for decision makers in the alternative choices. Sixth, Model Brinkerhoff. In this model, there are three types of evaluation is based on the combination of elements, namely; Fixed vs Emergent Design, Formative vs. summative Evaluation, and experimental and quasiexperimental design natural inquiry.

Seventh, illuminative Model. This model is more emphasis on opened-qualitative evaluation. Evaluation activities attribute to learning milieu, in the context of the school as material and psychosocial environment, where the teachers and students can interact. The evaluation results are more descriptive and interpretation, not the measurement and prediction. These models use more judgment. Eighth, Responsive Model. This model emphasizes the qualitative-naturalistic approach. The purpose of evaluation is to understand all the components of the learning program through a variety of different viewpoints.

Integrated curriculum is a form of curriculum that eliminates the boundaries between the different subjects and presenting materials in the form of a whole unit (Oemar Hamalik, 1993: 33). Thus, integral curriculum components integrate subjects, therefore the boundaries of these subjects had no visible anymore because 
the encapsulated in the unit. The approach in curriculum integration is to give the opportunity to develop the potential of students, strategies and understanding within a framework. Moreover, the teachers should use varying strategies to develop students' multiple intelligence. Model curriculum integration basically establish the principle of discovery and inquiry.

The goals of curriculum integration include the following (Rusmilati R, 2007: 49): integrating learning context, content and process skills in one or more subjects; plan learning by providing opportunities for students to interact (cooperative learning); arouses students to realize learning goals; give authority to the students to think about how they find out fun learning; give confidence to the students to some of the things in the learning process, to increase the sense of responsibility; able to meet and express themselves in different learning styles, engaging students in collecting and processing the latest information actively, motivating students to be independent, creative, innovative, and adaptive, and develop their multiple intelligence; and further strengthen the relationship between friends and teachers who will eventually good intertwined.

The characteristics of organizational forms of curriculum (integrated curriculum) include (Sa'ud, 2008: 116): based on the educational philosophy of Pancasila democracy; based on gestalt learning theory in psychology; based on the foundation of sociology and socio-cultural; based on their interests and needs and level of development of learners; supported by all subjects or areas of study; delivery system by using the system of teaching unit, the unit of lessons experience; and the role of teachers as well as active learners role, which the student are even more prominent active and teachers tend to act as mentors or facilitators.

On a practical scale, Integrated Curriculum has several advantages and benefits, among others (Sokib, 2009: 29-30): integrated curriculum is based on students' interests and experiences; in the implementation of the curriculum, it provides meaningful experiences to students, because students are required to solve the problem based learning with what happened to them in their everyday lives; learning resources are used not just limited to textbooks, but the surrounding environment learners can be used as a learning 
resource; social skills formed learners in the learning process, this is because the students are confronted with practical experiences in the learning process.

In addition to these advantages, integrated curriculum has weaknesses, among others (Sokib, 2009: 20-21): most teachers inadequate to understand on the implementation of an integrated curriculum, consequently the task of teachers is very heavy, it is because teachers must organize or combines a variety of standard and basic competencies in all subjects related; the use of facilities and infrastructure in learning is very diverse, so it can complicate on the implementation; organization of knowledge in the curriculum is not logical and not systematic, as it always changes according to the planned issue of teachers and students; and this integrated curriculum emphasizes the learning process of the learning outcomes.

The Relevant of research is used as a comparison in order to avoid the manipulation of a scientific work and strengthen that research by the author, which really has not been observed by others. Relevance of the previous researchers ever conducted are as follows:

Research conducted by Aida Rusmilati R titled "Model Curriculum Integration In international school in SMAN 3 Madiun." Based on the results of the study concluded that in general the objectives, content, strategy and organization of curriculum integration in accordance with international curriculum adapted model pengembambangan curriculum adheres to the principle of integration, which are The grass root development models and the demonstration models, because the curriculum is based on the integration of initiatives and development efforts of the school, as an implementation of a policy. Implementation of curriculum integration target is to students, teachers as policy implementers, and the school as a facilitator in setting up a means of learning and facilitate all the needs of teachers and students in the learning process (Rusmilati R, 2007: 165). Research conducted by Abdul Shokib entitled "Implementation of the Concept Development of Curriculum Integration (Integrated Curriculum) in SMP Al-Hikmah Surabaya, the result of research that have been using the school curriculum integration has been developed by teachers on that school (Sokib, 2009: 136). 


\section{b. The quality difference of assessment Instrument between the lecturer' background of study on Education and Non- Education.}

To know the difference between faculty quality assessment instrument of educational and non-educational backgrounds, researchers only looked through the average quality of the instrument between the faculty of education and non education. Based on the results of the analysis, it showed that the average quality assessment instrument in the group of education lecturers at 40.68 with a percentage of $67.8 \%$ while the average quality assessment instrument in the group of non-education lecturers at 43.02 with the percentage of $71.69 \%$. Thus, it can be argued that the quality assessment instrument in the group of non-education lecturers is better than the quality assessment instrument in the group of education lecturers. That is, there is a difference in quality assessment instrument between education and non education lecturers in the implementation of curriculum integration UIN Sultan Syarif Kasim Riau.

\section{Discussion}

Based on the survey results, the quality of assessment instruments of the implementation of curriculum integration UIN Sultan Syarif Kasim Riau classified generally as "GOOD" with a percentage of $70.57 \%$. Nevertheless, the assessment instrument in the curriculum integration has not been applied. It is seen from the results of studies showing that the item 12, which shows the integration is still relatively very less. This indicates that the instrument assessments made by educators of UIN Sultan Syarif Kasim Riau on the concept of curriculum integration has not been done well.

The following will describe the quality of assessment instruments in the implementation of integrated curriculum for each course. The quality of assessment instrument in the course of Hadith obtained $71.67 \%$ with a score of 43 which is in the interval 41-44 categorized ENOUGH. The quality of assessment instrument in the course on Islamic Economic System acquired 66.67\% with a score of 40 which is in the interval $47-40$ categorized LESS. The quality of assessment instrument in the course of Micro-economics theory gained $60 \%$ with a score of 36 which is in the interval 33-36 
categorized VERY LESS. The quality of assessment instruments in the course of History of Islamic Civilization acquired 63.33\% with a score of 38 at the interval $37-40$ categorized LESS. The quality of assessment instrument in the course of Tafsir Tarbawi obtained 70\% with a score of 42 at the interval 41-44 categorized GOOD. The quality of assessment instrument of the course Teaching Profession and Ethics gained $65 \%$ with a score of 39 at the interval $37-40$ categorized LESS. The quality of assessment instrument in the course Aqidah II acquired $63.33 \%$ with a score of 38 at the interval $37-40$ categorized LESS.

The quality of assessment instruments in the course of Sociology of Education obtained $63.33 \%$ with a score of 38 at the interval 37-40 categorized LESS. The quality of assessment instruments in the subject of Islam and Tamaddun Melayu obtained $58.33 \%$ with a score of 35 at the interval 33-36 categorized VERY LESS. The quality of assessment instruments in the subject History of Islam in Riau obtained $63.33 \%$ with a score of 38 at the interval $37-40$ categorized LESS. The quality of assessment instruments in the course pupils Development gained $68.33 \%$ with a score of 41 at the interval 41-44 categorized ENOUGH. The quality of assessment instruments in the course of Hadith Tarbawi obtained $66.67 \%$ with a score of 40 at the interval $37-40$ categorized LESS. The quality of assessment instruments in the course Fiqh Munakahat obtained 65\% with a score of 39 at the interval 37-40 categorized LESS.

The quality of assessment instrument in the course Pendalaman Materi PAI obtained $65 \%$ with a score of 39 at the interval $37-40$ categorized LESS. The quality of assessment instrument in the course Study Qur'an II acquired $73.33 \%$ with a score of 44 at the interval 41-44 categorized ENOUGH. The quality of assessment instrument in the course Curriculum Development and Assessing Fiqh obtained $56.67 \%$ with a score of 34 at the interval 33-36 categorized VERY LESS. The quality of assessment instruments in Usul Fiqh gained $75 \%$ with a score of 45 at the interval $45-48$ categorized GOOD. The quality of assessment instruments in the course of Hadith Ahkam obtained $61.67 \%$ with a score of 37 at the interval $37-40$ categorized LESS. The quality of assessment instruments in the course of Animal Health acquired $63.33 \%$ with a score of 38 at the interval $37-40$ 
categorized LESS. The quality of assessment instruments in the course Introduction to Economics gained $66.67 \%$ with a score of 40 at the interval 37-40 categorized LESS.

The quality of assessment instrument in the course of Hadith Ahkam obtained $75 \%$ with a score of 45 at the interval $45-$ 48 categorized GOOD. The quality of assessment instrument in the course Statistics obtained $71.67 \%$ with a score of 43 at the interval 41 44 categorized ENOUGH. The quality of assessment instrument in the course Design of Experiments obtained $78.33 \%$ with a score of 47 at the interval 45-48 categorized GOOD. The quality of assessment instrument in the course Science and Technology of Poultry Production gained $86.67 \%$ with a score of 52 at the interval $49-52$ categorized EXCELLENT. The quality of assessment instrument in the course of Mathematics obtained $68.33 \%$ with a score of 41 at the interval 41-44 categorized ENOUGH. The quality of assessment instrument in the course Sturdy Qur'an gained 70\% with a score of 42 at the interval 41-44 categorized ENOUGH.

The quality of assessment instrument in the course Animal Feeding Industry gained $71.67 \%$ with a score of 43 at the interval 41 44 categorized ENOUGH. The quality of assessment instrument in the course the Qur'an gained $80 \%$ with a score of 48 at the interval 45-48 categorized GOOD. The quality of assessment instrument in the course Fundamentals of Management acquired $68.33 \%$ with a score of 41 at the interval 41-44 categorized ENOUGH. The quality of assessment instrument in the course Akhlaq gained $78.33 \%$ with a score of 47 at the interval 45-48 categorized GOOD. The quality of assessment instrument in the course Biology acquired $73.33 \%$ with a score of 44 at the interval 41-44 categorized ENOUGH.

The quality of assessment instrument in the course Fiqh obtained $86.67 \%$ with a score of 52 at the interval $49-52$ categorized EXCELLENT. The quality of assessment instrument in the course the introduction of Animal Nutrition obtained $73.33 \%$ with a score of 44 at the interval 41-44 categorized ENOUGH. The quality of assessment instrument in the course the Parks and Landscape gained $75 \%$ with a score of 45 at the interval 45-49 categorized GOOD. The quality of assessment instrument in the course Rural Sociology, Communication and Agricultural Extension gained 80\% with a 
score of 48 at the interval $45-48$ categorized GOOD. The quality of assessment instrument in the course Physics acquired $76.67 \%$ with a score of 46 at the interval $45-48$ categorized GOOD. The quality of assessment instrument in the subject of Chemistry gained $73.33 \%$ with a score of 44 at the interval 41-44 categorized ENOUGH. The quality of assessment instrument in the course of Botany obtained $70 \%$ with a score of 42 at the interval $41-44$ categorized ENOUGH.

The quality of assessment instrument in the course Milk Fermentation Technology acquired $81.67 \%$ with a score of 49 at the interval 45-48 categorized GOOD. The quality of assessment instrument in the course Science and Behavior Cattle Point earned $70 \%$ with a score of 42 at the interval 41-44 categorized ENOUGH. The quality of assessment instrument in the course Science Arts, Livestock and Animal Hope acquired $81.67 \%$ with a score of 49 at the interval 49-52 categorized EXCELLENT. The quality of assessment instrument in the course Introduction to Agricultural Science obtained $61.67 \%$ with a score of 49 at the interval $49-52$ categorized EXCELLENT. The quality of assessment instrument in the course Feasibility Study Ranch obtained $66.67 \%$ with a score of 40 at the interval 37-40 categorized LESS. The quality of assessment instrument in the course Citizenship Education acquired 68.33\% with a score of 41 at the interval 41-44 categorized ENOUGH. The quality of assessment instrument in the course Tissue Culture acquired $71.67 \%$ with a score of 43 at the interval $41-44$ categorized ENOUGH. The quality of assessment instrument in the course Biodiversity acquired $68.33 \%$ with a score of 41 at the interval $41-44$ categorized ENOUGH. The quality of assessment instrument in the course Animal Feeding of Biotechnology gained $73.33 \%$ with a score of 44 at the interval 41-44 categorized ENOUGH.

The quality of assessment instrument in the course Goat and Sheep Science obtained $73.33 \%$ with a score of 44 at the interval 41-44 categorized ENOUGH. The quality of assessment instrument in the course Soil Science and Fertilization Fertility gained 58.33\% with a score of 35 at the interval 33-36 categorized VERY LESS. The quality of assessment instrument in the course Abatoir and Mechanical Cutting Livestock gained $75 \%$ with a score of 45 at the interval 45-48 categorized GOOD. The quality of assessment 
instrument in the course Laboratories acquired $61.67 \%$ with a score of 37 at the interval 37-40 categorized LESS. The quality of assessment instrument in the course Animal Reproduction Science gained $70 \%$ with a score of 42 at the interval $41-44$ categorized LESS. The quality of assessment instrument in the course Engineering Laboratories acquired $63.33 \%$ with a score of 38 at the interval $37-40$ categorized LESS. The quality of assessment instrument in the course Agrostologi obtained $71.67 \%$ with a score of 43 at the interval $41-44$ categorized ENOUGH. The quality of assessment instrument in the course Aqidah II acquired $71.67 \%$ with a score of 43 at the interval 41-44 categorized ENOUGH.

The quality of assessment instrument in the course Packaging and Storage Technology acquired $78.33 \%$ with a score of 47 at the interval 45-48 categorized GOOD. The quality of assessment instrument in the course Post Harvest Technology gained $80 \%$ with a score of 48 at the interval 45-48 categorized GOOD. The quality of assessment instrument in the course Islamic Philosophy I obtained $73.33 \%$ with a score of 44 at the interval $41-44$ categorized ENOUGH. The quality of assessment instrument in the course Manuscript Studies obtained $75 \%$ with a score of 45 at the interval 45-48 categorized GOOD. The quality of assessment instrument in the course Urban Sociology obtained 70\% with a score of 42 at the interval 41-44 categorized ENOUGH. The quality of assessment instrument in the course Sufism IV gained $68.33 \%$ with a score of 41 at the interval 41-44 categorized ENOUGH. The quality of assessment instrument in the course Western Philosophy II acquired $63.33 \%$ with a score of 38 at the interval $37-40$ categorized LESS.

The quality of assessment instrument in the course Science of Tawheed obtained $70 \%$ with a score of 42 at the interval 41-44 categorized ENOUGH. The quality of assessment instrument in the course Fiqh Mu'amalah obtained $63.33 \%$ with a score of 38 at the interval 37-40 categorized LESS. The quality of assessment instrument in the course The Discussion of Hadiths II acquired $76.67 \%$ with a score of 46 at the interval 45-48 categorized GOOD. The quality of assessment instrument in the course Research Methodology of Hadits acquired $76.67 \%$ with a score of 46 at the interval $45-48$ categorized GOOD. The quality of assessment instrument in the 
course SPPH II acquired $61.67 \%$ with a score of 37 at the interval 37-40 categorized LESS. The quality of assessment instrument in the course Khath Qur'an gained 55\% with a score of 33 at the interval 3336 categorized VERY LESS.

The quality of assessment instrument in the course Tahfidz Al-Qur' an I obtained 65\% with a score of 39 at the interval $37-40$ categorized LESS. The quality of assessment instrument in the course Tahfidz Hadith I obtained $66 \%$ with a score of 39 at the interval $37-$ 40 categorized LESS. The quality of assessment instrument in the course Mantiq Science obtained $68.33 \%$ with a score of 41 at the interval 41-44 categorized ENOUGH. The quality of assessment instrument in the course Research Methodology of Philosophy acquired $68.33 \%$ with a score of 41 at the interval $41-44$ categorized ENOUGH. The quality of assessment instrument in the course Usul Fiqh II acquired $73.33 \%$ with a score of 44 at the interval $41-44$ categorized ENOUGH. The quality of assessment instrument in the course Virtue Sufism gained $63.33 \%$ with a score of 38 at the interval 37-40 categorized LESS.

The quality of assessment instrument in the course Political Islam gained $66.67 \%$ with a score of 40 at the interval $37-40$ categorized LESS. The quality of assessment instrument in the course Sociology of Islam gained $65 \%$ with a score of 39 at the interval 37 40 categorized LESS. The quality of assessment instrument in the course Beliefs acquired $78.33 \%$ with a score of 47 at the interval 45 48 categorized GOOD. The quality of assessment instrument in the course Study Hadith obtained $75 \%$ with a score of 45 at the interval 45-48 categorized GOOD. The quality of assessment instrument in the course Science Kalam II acquired $71.67 \%$ with a score of 43 at the interval 41-44 categorized ENOUGH. The quality of assessment instrument in the course Orientalism acquired $76.67 \%$ with a score of 46 at the interval 45-48 categorized GOOD.

The quality of assessment instrument in the course Research Methodology of Theology acquired $71.67 \%$ with a score of 43 at the interval 41-44 categorized ENOUGH. The quality of assessment instrument in the course Islamic Philosophy III obtained $71.67 \%$ with a score of 43 at the interval $41-44$ categorized ENOUGH. The quality of assessment instrument in the course Social Research Methodology 
acquired $78.33 \%$ with a score of 47 at the interval $45-48$ categorized GOOD. The quality of assessment instrument in the course Religion Antrolpology obtained $66.67 \%$ with a score of 40 at the interval $37-40$ categorized LESS. The quality of assessment instrument in the course Hadith Thematic Aqidah obtained 83.33\% with a score of 50 at the interval 49-52 categorized EXCELLENT. The quality of assessment instrument in the course Philosophy of Human obtained $71.67 \%$ with a score of 43 at the interval 41-44 categorized ENOUGH. The quality of assessment instrument in the course Science of Tawheed obtained $76.67 \%$ with a score of 46 at the interval $45-48$ categorized GOOD.

In addition, the courses are also seen by the assessment indicators instrument in the implementation of curriculum integration. First, the quality of the item conformity assessment instrument with indicator gained about $82 \%$ with a score of 361 at the interval 357-444 categorized EXCELLENT. Second, the quality of the item assessment instrument clarity obtained $78 \%$ with a score of 339 at the interval 269-356 categorized GOOD. Third, the quality assessment instrument in the formulation item sentence of direction obtained $85 \%$ with a score of 371 at the interval 357-444 categorized EXCELLENT. Fourth, the quality of the item assessment instrument on the accuracy of material order obtained $86 \%$ with a score of 373 at the interval 357-444 categorized EXCELLENT. Fifth, the quality assessment instrument in the item description clarity was obtained about $83 \%$ with a score of 363 at the interval $357-444$ categorized EXCELLENT. Sixth, the quality assessment instrument on the depth of material items obtained $79 \%$ with a score of 342 at the interval 269356 categorized GOOD. Seventh, the quality of the item assessment instrument engineering / systematic writing obtained about $55 \%$ with a score of 239 at the interval 181-268 categorized ENOUGH. Eighth, the quality of the item assessment instrument providing feedback obtained 55\% with a score of 238 at the interval 181-268 categorized ENOUGH. Ninth, the quality assessment instrument in terms of items clarity obtained $80 \%$ with a score of 350 in the interval 269356 categorized GOOD. Tenth, the quality assessment instrument in using standardized Indonesian language gained $76 \%$ with a score of 331 at the interval 269-356 categorized GOOD. Eleventh, the quality assessment instrument at about the level of item diversity $62 \%$ with a score of 270 in the interval 269-356 categorized GOOD. 
Twelfth, the quality of the item assessment instrument linkages between courses gained $25 \%$ with a score of 107 at the interval 93180 categorized LESS.

Based on the results of the analysis, it can be promoted that an assessment instrument in the implementation of curriculum integration UIN Sultan Syarif Kasim Riau has not been fully implemented. It is seen from the quality of their item assessment instrument on linkages between courses classified as LESS with a score of 107. The linkage between these courses shows the aspect of curriculum integration. Obviously, it can be assumed that educators have not been able to implement curriculum integration that can affect the vision UIN Sultan Syarif Kasim Riau. Nevertheless, the classical instrument ratings is included on the GOOD category. However, when viewed in the classical quality assessment instrument in the implementation of curriculum integration of acquired $70.57 \%$ with a score of 3684 in the interval 3552-4387 categorized GOOD.

\section{Conclusion}

Based on the analysis of data, the conclusions are: 1) the quality of assessment instrument in the implementation of curriculum integration UIN Suska Riau obtained through the test description of the item assessment. Based on the results of research and analysis the researchers, it is found that the quality assessment instrument classified as "GOOD" with a percentage of 70.57\%; and 2) based on the results of the analysis, it showed that the average quality of assessment instruments in the group education lecturer at 40.68 with a percentage of $67.8 \%$ while the average quality assessment instrument in the group of non education lecturer at 43.02 with the percentage of $71.69 \%$. Thus, it can be argued that the quality assessment instrument in the group of non-education lecturers is better than the quality assessment instrument in the group of education lecturers. That is, there is a significant difference in the quality of assessment instrument between education and noneducation lecturers in the implementation of curriculum integration UIN Sultan Syarif Kasim Riau. 


\section{DAFTAR PUSTAKA}

Arifin, Zainal. 2010. Evaluasi Pembelajaran Prinsip, Teknik, Prosedur. Bandung: Remaja Rosdakarya.

Arikunto, Suharsimi. 2010. Dasar-Dasar Evaluasi Pendidikan. Jakarta: Bumi Aksara.

Djaali dan Pudji Muljono. 2004. Pengukuran dalam Bidang Pendidikan. Jakarta: PPS UNJ.

Hajar, Ibn. 1996. Dasar-dasar Metodologi Penelitian Kuantitatif dalam Pendidikan. Jakarta: Raja Grafindo Persada.

Hamalik, Oemar. 1993. Proses Belajar Mengajar. Jakarta: Bumi Aksara.

Mawardi Lubis and Zubaedi. 2008. Evaluasi Pendidikan Nilai Perkembangan Moral Keagamaan Mahasiswa PTAIN. Bengkulu: Pustaka Pelajar.

Rusmilati R., Aida. 2007. Model Kurikulum Integrasi Pada Rintisan Sekolah Bertaraf Internasional di SMA Negeri 3 Madiun. Malang: Universitas Malang. Disertasi.

Saefudin Sa’ud, Udin. 2008. Inovasi Pendidikan. Bandung: Alfabeta.

Sokib, Abdul. 2009. Implementasi Konsep Pengembangan Kurikulum Integrasi (Integrated Curiculum) di SMP Al-Hikmah Surabaya. Surabaya: IAIN Sunan Ampel. Skripsi.

Stephen Isaac dan William B. Michael. 1982. Handbook In Research and Evaluation. California: EdITS.

Sudijono, Anas. 1995. Pengantar Evaluasi Pendidikan. Jakarta: PT. Raja Grafindo Persada.

Sukardi. 2008. Evaluasi Pendidikan, Prinsip \& Operasionalnya. Jakarta: Bumi Aksara.

Yusuf, Nasharuddin. 2011. Integrasi dan Islamisasi Ilmu-Ilmu Sosial di Lembaga Pendidikan Islam. Pekanbaru: Potensia Jurnal Kependidikan Islam. 